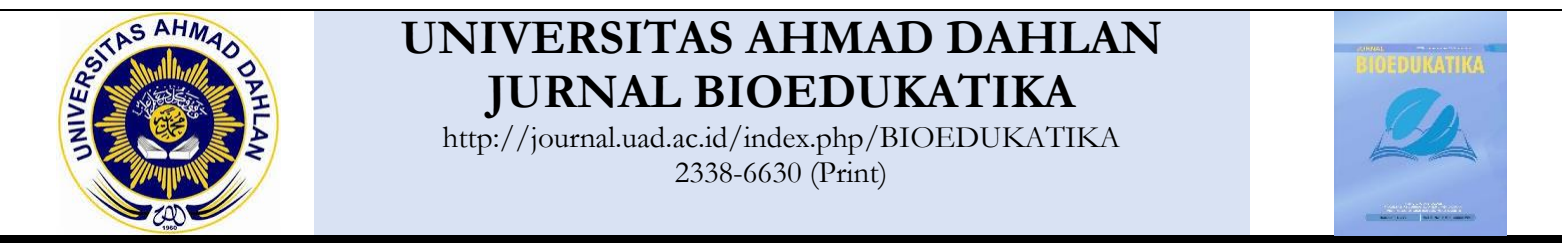

\title{
Pengembangan video mengenai mangrove sebagai media pembelajaran di sekolah menengah atas (SMA) dan masyarakat di pesisir jambi
}

\author{
Endah Puspita ${ }^{1}$, Bambang Hariyadi ${ }^{2}{ }^{*}$, Muswita $^{3}$ \\ Program Studi Pendidikan Biologi FKIP, Universitas Jambi, Jl. Raya Jambi-Ma. Bulian, KM. 15, 36361, Mendalo Indah, Jambi, Indonesia \\ ${ }^{1}$ epuspita45@gmail.com; ${ }^{2}$ bambang_h@unja.ac.id; ${ }^{3}$ muswita.fkip@unja.ac.id \\ *korespondensi penulis
}

\begin{tabular}{ll}
\hline Informasi artikel & \\
\hline Sejarah artikel: & \\
Diterima & 2 Februari 2018 \\
Revisi & 13 Desember 2018 \\
Dipublikasikan & 17 Desember 2018 \\
\hline
\end{tabular}

Kata kunci:

Mangrove

Media Pembelajaran

Media Video \begin{abstract}
ABSTRAK
Penelitian ini bertujuan menghasilkan media pembelajaran berupa video mengenai mangrove yang dapat digunakan oleh siswa SMA serta masyarakat, khususnya yang tinggal di kawasan pesisir. Pengembangan media dilakukan menggunakan model ADDIE. Data yang dikumpulkan meliputi data kualitatif dan kuantitatif. Pengumpulan data menggunakan instrumen berupa lembar validasi untuk ahli materi dan ahli media, serta angket yang diberikan kepada siswa dan masyarakat. Ujicoba produk dilakukan pada 12 siswa di SMAN 6 Tanjung Jabung Timur Provinsi Jambi serta 9 kelompok masyarakat di Desa Sungai Itik, Kecamatan Sadu, Tanjung Jabung Timur. Hasil validasi produk oleh ahli materi diperoleh penilaian sebesar $85 \%$ (kategori sangat layak) dan hasil validasi produk oleh ahli media diperoleh nilai sebesar $80 \%$ (kategori layak). Ujicoba pada siswa SMA menunjukkan adanya tanggapan yang sangat baik $(85,4 \%)$ terhadap video yang dihasilkan. Demikian pula halnya dengan ujicoba pada kelompok masyarakat yang memberikan nilai 84,8\% (kategori sangat baik). Berdasarkan hasil tersebut, video mengenai mangrove layak dan baik digunakan dalam membelajarkan mengenai mangrove, baik dari segi kualitas materi maupun media. Video pembelajaran mengenai mangrove dapat dimanfaatkan sebagai alternatif media pembelajaran untuk menjangkau lapisan masyarakat yang lebih luas.
\end{abstract}

Key word:

Mangrove

Instructional Media

Video Media

\section{ABSTRACT}

The development of mangrove video instructional media for high school students and societies in the coastal areas of Jambi. This study aims to produce video learning media about mangrove. The media development used the ADDIE model. Data in this research include qualitative and quantitative data, collected by means of research instruments in the form of validation sheets for material and media expert. In addition questionnaires were filled in by students of SMAN 6 East Tanjung Jabung as well as 9 community groups in the Sungai Itik Village, East Tanjung Jabung to assess the feasibility of the media. Video validation by material expert obtained value of $85 \%$ (very good category), where as validation by media expert indicate value of $80 \%$ (good category). Students' responses to the videos are categorized as excellent $(85,4 \%)$. Product trial with the community of Sungai Itik obtained public response of $84,8 \%$ (very good category). Based on the results obtained from the expert team, as well as responses from students and the community, the mangrove learning video is considered feasible in terms of both material and the media quality. The video can be used as a learning medium for mangrove learning either for students or for community.

\section{Pendahuluan}

Provinsi Jambi memiliki garis pantai di sepanjang pesisir timur yang terdapat di Kabupaten Tanjung Jabung Timur dan Kabupaten Tanjung Jabung Barat. Pantai yang terdapat di Provinsi Jambi
Copyright (C) 2018 Unifversitas Ahmad Dahlan

berbeda dengan pantai-pantai lain yang memiliki pemandangan yang indah berpasir putih; pantai di Jambi didominasi oleh pantai yang berpasir hitam dan berlumpur, yang ditumbuhi mangrove. Hutan mangrove dengan berbagai jenis hewan dan tumbuhan 
yang ada di dalamnya memiliki peran ekologis yang penting dalam menjaga kelestarian ekosistem di sekitarnya. Jenis-jenis mangrove merupakan salah satu kekayaan keanekaragaman flora di Indonesia. Mangrove merupakan vegetasi dengan tingkat produktivitas yang tinggi jika dibandingkan dengan hutan darat tropika (Saparinto, 2007).

Meningkatnya kegiatan ekonomi yang semakin pesat, mengakibatkan banyak hutan mangrove yang dirambah dan dialihfungsikan. Misalnya, pembangunan pelabuhan di Ujung Jabung di Kabupaten Tanjung Jabung Timur yang pada akhirnya memaksa penebangan hutan mangrove di sekitarnya. Meskipun hutan mangrove sesungguhnya memiliki nilai ekonomis dan ekologis yang tinggi, kurangnya pemahaman siswa dan masyarakat akan pentingnya mangrove, menyebabkan kurangnya kepedulian mereka akan kelestarian hutan mangrove tersebut.

Hasil wawancara dengan guru biologi dan observasi pada siswa kelas XI IPA SMAN 6 Tanjung Jabung Timur menunjukkan penggunaan media pembelajaran yang masih kurang variatif. Akibatnya, masih banyak siswa yang kurang tertarik terhadap pelajaran biologi dan menganggap pelajaran biologi sebagai pelajaran yang membosankan. Lingkungan belajar dalam kelas kurang interaktif jika hanya mengandalkan guru, buku teks, dan penjelasan. Penggunaan grafik, video dan media lainnya dapat membantu memusatkan perhatian siswa sehingga kegiatan belajar menjadi lebih menarik (Zhang, Zhou, Briggs, \& Nunamaker, 2006). Khusus untuk materi ekosistem, masih sangat sedikit media yang menyajikan materi dengan menarik, khususnya mengenai mangrove. Berdasarkan observasi yang telah dilakukan, generasi muda (siswa) masih belum memahami mengenai mangrove. Hal ini juga disebabkan belum adanya media yang menjelaskan materi ekosistem khususnya hutan mangrove. Penelitian yang dilakukan Restu, Berutu, Ridha Syafii Damanik, \& Suriani Harefa, (2017), menunjukkan bahwa ekosistem mangrove dapat digunakan sebagai media dan sumber belajar untuk pendidikan tingkat SMA. Namun penelitian ini masih terbatas pada penggunaan ekosistem mangrove secara langsung sebagai media. Sementara pengemasan ekosistem mangrove menjadi bentuk media terutama video masih kurang.

Meskipun SMAN tersebut telah memiliki fasilitas ICT berupa laptop dan proyektor, tetapi fasilitas tersebut belum sepenuhnya dimanfaatkan secara optimal untuk mengembangkan pembelajaran yang lebih variatif. Hasil wawancara dengan Perangkat Desa di Desa Sungai Itik Tanjung Jabung Timur menyebutkan bahwasanya masyarakat setempat hanya mengetahui mangrove sebagai penahan abrasi dan pemanfaatan mangrove hanya sebatas sebagai bahan papan. Hal ini menyebabkan belum maksimalnya upaya pelestarian dan pemanfaatan mangrove. Pemahaman dan tindakan nyata pelestarian mangrove oleh masyarakat, khususnya generasi muda (siswa) sangat penting untuk menjaga dan melestarikan mangrove. Masyarakat, dimulai dari generasi muda (siswa) memiliki peran yang cukup dalam kegiatan menjaga, memelihara maupun rehabilitasi hutan mangrove (Pontoh, 2011). Oleh karena itu perlu dikembangkan sebuah media yang dapat memberikan edukasi tentang mangrove dan pelestariannya. Ada banyak cara yang dapat dilakukan untuk memudahkan siswa dan masyarakat dalam memahami pentingnya mangrove, salah satunya dengan memanfaatkan media yang dapat mendukung pembelajaran seperti video pembelajaran. Pembelajaran dengan menggunakan media seperti video dapat memberikan hasil belajar yang lebih baik dibandingkan pembelajaran yang tidak menggunakan media (Isiaka, 2007).

Penggunaan media yang lebih modern dan menarik seperti media audiovisual dapat menjadi salah satu alternatif dan menarik perhatian siswa dan masyarakat. Penggunaan media audiovisual juga efektif pada siswa dan masyarakat yang minat bacanya masih rendah. Menurut Choi \& Johnson (2005) pembelajaran menggunakan video menghasilkan pesan yang lebih mudah diingat serta dapat meningkatkan minat belajar secara signifikan dibandingkan pembelajaran yang hanya menggunakan teks. Penggunaan video memberikan kesempatan kepada siswa dan masyarakat untuk belajar secara mandiri.

Video selama ini lebih dikenal sebagai media hiburan. Seiring berjalannya perkembangan zaman, teknologi video juga mulai diadaptasi, dari yang dulunya hanya memuat konten hiburan, kini juga berfungsi sebagai media pembelajaran yang banyak diisi dengan konten pendidikan (keilmuan). Proses pembelajaran yang modern dapat diciptakan dengan mengkondisikan agar siswa dapat lebih tertarik dan bersemangat dalam belajar, sehingga siswa akan lebih mudah memahami materi demi tercapainya pembelajaran yang sukses. Hsin \& Cigas (2013) menyatakan bahwa video pendek dapat digunakan untuk menarik minat dan memotivasi siswa dalam pembelajaran.

Observasi yang dilakukan penulis menunjukkan bahwa sebagian besar siswa dan masyarakat lebih menyukai penggunaan media jenis audiovisual dibandingkan media cetak. Siswa dapat belajar lebih mendalam dari pembelajaran dengan multimedia yang menyajikan kata-kata dan gambar dibandingkan belajar dari media yang hanya menyajikan kata-kata (Mayer, 2003; Salina et al., 2012). Video berguna 
untuk menyegarkan dan memperkuat konsep. Penelitian Handziko \& Suyanto (2015) juga menunjukkan bahwa penggunaan DVD pada pembelajaran suksesi ekosistem Gunung Merapi menghasilkan perbedaan dan pengaruh yang signifikan terhadap penguasaan konsep suksesi. Selain itu penelitian Yusriya, Santosa, \& Priyono (2014) juga menunjukkan bahwa siswa memberikan tanggapan positif terhadap penggunaan video pembelajaran pada materi klasifikasi hewan. Hal ini ditunjukkan dengan $86,7 \%$ siswa memberikan tanggapan sangat baik dan 5\% memberikan tanggapan baik. Sementara itu, penilaian video oleh ahli media dan ahli materi menghasilkan rata-rata skor 93,75\% dengan kriteria sangat baik.

Beberapa penelitian yang telah dilakukan, diketahui bahwa video dapat meningkatkan motivasi belajar, kemampuan memahami, serta hasil belajar (Hadi, 2017; Kurniawan \& Soeprajitno, 2017). Selain itu, media video juga efektif dalam membangun karakter disiplin siswa (Hakim, 2017). Namun penelitian-penelitian yang telah dilakukan ini, masih terbatas pada pembelajaran di kelas (siswa) dan belum menyentuh lapisan masyarakat secara langsung. Mempertimbangkan pentingnya pengembangan media pembelajaran mengenai mangrove baik bagi siswa Sekolah Menengah Atas (SMA) maupun masyarakat, maka penulis mengembangkan media pembelajaran berupa video mengenai mangrove, khususnya untuk siswa Sekolah Menengah Atas (SMA) dan masyarakat di daerah Jambi.

\section{Metode}

Penelitian ini termasuk jenis penelitian pengembangan (Research and Development) yang merupakan gabungan anatara penelitian kuantitatif dan kualitatatif (Mixed Method). Metode penelitian dan pengembangan ini digunakan untuk menghasilkan produk tertentu, termasuk pengujian keefektifan produk yang dihasilkan (Sugiyono, 2014). Model pengembangan yang digunakan untuk mengembangkan produk video dengan model ADDIE (Analysis, Design, Development, Implementation, and Evaluation). Mengacu pada Lee \& Owens (2004), model ADDIE dipilih karena model ini merupakan model prosedural, yaitu model yang bersifat deskriptif, menunjukkan langkahlangkah yang jelas dan cermat untuk menghasilkan produk. Langkah-langkah dari model ADDIE yang digunakan untuk mengembangkan produk video tentang mangrove tersaji pada gambar 1 .

Produk yang dihasilkan sebelum dilakukan ujicoba kelompok siswa dan kelompok masyarakat dilakukan validasi antara lain validasi materi, validasi media. Tahap validasi oleh ahli materi, ahli media dan dilanjutkan dengan analisis data hasil validasi dan revisi. Adapun aspek penilaian untuk validasi media meliputi penggunaan bahasa, manfaat, tampilan video, unsur visual, unsur audio, kriteria video dan penyajian video. Sedangkan aspek penilaian untuk validasi materi meliputi relevansi isi video dengan tujuan pembelajaran, kejelasan isi materi, relevansi materi, penyajian, dan manfaat.

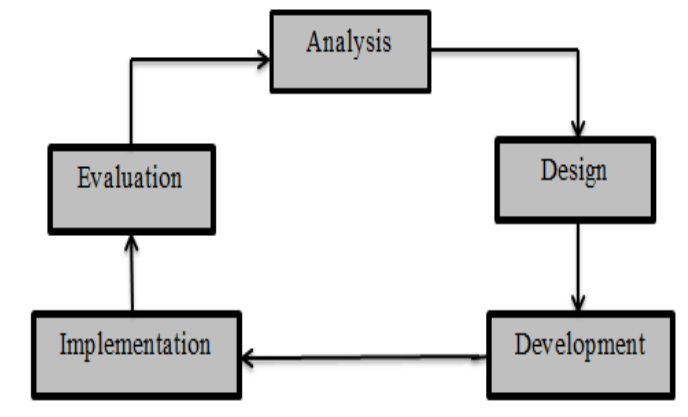

Gambar I. Proses pengembangan produk dengan model ADDIE (Lee \& Owens, 2004)

Tahap ujicoba kelompok siswa dilakukan pada 12 siswa, dengan menunjukkan produk video yang dikembangkan. Aspek tanggapan (penilaian) yang diperoleh dari siswa meliputi fungsi video, kriteria video, tampilan video, serta unsur audio dan unsur visual.

Tahap selanjutnya yakni ujicoba pada masyarakat yang dilanjutkan dengan wawancara. Ujicoba dilakukan pada sembilan kelompok masyarakat. Aspek penilaian yang diperoleh dari masyarakat meliputi fungsi video, kriteria video, tampilan video, serta unsur audio dan unsur visual. Hasil dari ujicoba ini dianalisis dan dijadikan acuan dalam revisi akhir produk. Penilaian dan revisi dimaksud untuk mendapatkan sejumlah masukan untuk perbaikan sehingga akhirnya didapatkan produk yang layak digunakan.

Ujicoba pada kelompok siswa dilakukan terhadap 12 orang siswa SMA dengan tingkat kemampuan yang bervariasi (rendah, sedang dan tinggi). Hal ini mengacu pada Setyosari (2012), yang menyatakan bahwa ujicoba melibatkan subjek yang terdiri atas 6-12 subjek. Selanjutnya siswa diminta untuk mengisi angket yang telah disediakan untuk mengetahui kelayakan dan tanggapan dari siswa terhadap produk video.

Ujicoba pada kelompok masyarakat dilakukan dengan wawancara. Ujicoba dilakukan terhadap sembilan kelompok masyarakat yang masing-masing terdiri atas empat orang, sehingga secara keseluruhan terdapat 36 subjek ujicoba masyarakat. Pemilihan subjek ujicoba dilakukan mengikuti Setyosari (2012), dimana ujicoba lapangan dilakukan terhadap kelompok yang lebih besar yakni 15-30 orang anggota masyarakat yang menjadi target penggunaan media. 
Jumlah tersebut dapat mewakili target populasi dan materi yang diujicobakan.

Penelitian ini menggunakan data kualitatif dan kuantitatif. Data kualitatif berupa data verbal berupa saran dan masukan ahli media dan ahli materi mengenai produk yang dikembangkan. Masukan dan komentar dari para validator juga menjadi acuan penulis dalam melakukan revisi produk yang dihasilkan. Data kuantitatif yang diperoleh berupa skor-skor alternatif jawaban yang diberikan validator, siswa dan masyarakat terhadap produk yang dikembangkan.

Instrumen penelitian yang digunakan dalam penelitian ini berupa angket yang diberikan kepada ahli materi, ahli media, siswa kelas XI IPA SMAN 6 Tanjung Jabung Timur dan masyarakat Desa Sungai Itik. Angket yang digunakan untuk validasi media dan materi menggunakan kombinasi angket jenis tertutup dan terbuka, sedangkan angket yang diberikan kepada siswa dan masyarakat untuk ujicoba produk merupakan angket tertutup. Pengisian angket pada masyarakat dilakukan dengan cara wawancara yang dilakukan oleh peneliti.

Analisis data secara kualitatif dilakukan terhadap saran dan masukan dari ahli media dan ahli materi. Keseluruhan data yang didapat selanjutnya dijelaskan dalam bentuk deskriptif. Data kualitatif ini juga berguna untuk memperbaiki produk yang dikembangkan. Mengacu pada Ali \& Ansori (2014), data kualitatif yang berbentuk kata-kata ini dianalisis dengan cara melakukan editing untuk memilah mana yang benar-benar data dan yang bukan merupakan data, misalnya kesan pribadi responden. Selanjutnya peneliti membuat kategori antara data yang dinilai penting dan kurang penting.

Data kuantitatif yang diperoleh melalui angket tertutup dan hasil wawancara selanjutnya dianalisis dengan menghitung skor yang diperoleh dari skala Likert. Angket validasi produk memiliki pilihanpilihan jawaban berupa data kuantitatif. Setiap kategori jawaban tersebut diberi skor agar memiliki skala nilai yang bersifat kuantitatif sehingga dapat dianalisis (Sugiyono, 2014). Kategori skala Likert yang digunakan terdiri atas empat skala yaitu sangat baik (skor 4), baik (skor 3), tidak baik (skor 2), dan sangat tidak baik (skor 1). Perolehan data dari penilaian hasil validasi dan ujicoba dengan Skala Likert yang telah selesai ditabulasi, selanjutnya dianalisis dengan menghitung persentase skor dari setiap jawaban item pertanyaan yang diberikan oleh responden menggunakan rumus Riduwan (2010):

$$
\text { persentase }(\%)=\frac{F}{N} \times 100 \%
$$

Persentase (\%) adalah persentase sub variabel. F adalah jumlah nilai tiap sub variabel, dan $\mathrm{N}$ adalah jumlah skor maksimum. Data yang telah selesai dianalisis dan diperoleh persentase skor secara keseluruhan dari beberapa aspek variabel yang dinilai selanjutnya ditentukan apakah media pembelajaran yang dihasilkan termasuk dalam kategori sangat baik, baik, tidak baik, atau sangat tidak baik berdasarkan skala penilaian produk. Interpretasi skor untuk isi materi dan desain media video yakni: skor 48,76-60 (sangat layak), 37,51-48,75 (layak), 26,26-37,50 (tidak layak), dan 15-26,25 (sangat tidak layak). Interpretasi skor untuk penilaian ujicoba oleh siswa yakni: skor 391-480 (sangat baik), 301-390 (baik), 211-300 (tidak baik), dan 120-210 (sangat tidak baik), sedangkan interpretasi skor untuk penilaian hasil wawancara masyarakat yakni: skor 1171-1440 (sangat baik), 901-1710 (baik), 631-900 (tidak baik), dan 360-630 (sangat tidak baik). Penelitian ini hanya dilakukan hingga tahap ujicoba. Untuk mengetahui efektifitas media video mangrove, perlu dilakukan penelitian lanjutan yaitu eksperimen untuk membandingkan antar kelas kontrol dan kelas eksperimen sehingga diketahui apakah produknya efektif.

\section{Hasil dan pembahasan}

Pada validasi materi tahap pertama diperoleh skor 38 yang termasuk kategori "layak". Media dinyatakan layak diujicoba dengan revisi. Meskipun demikian, revisi tetap dilakukan karena masih banyak terdapat kesalahan, yakni perbaikan mengenai konsep mangrove, perbaikan nama ilmiah dari spesies, perbaikan pada skema zonasi mangrove, penambahan beberapa materi yang relevan, dan perbaikan pada beberapa gambar. Perbaikan dilakukan sesuai dengan saran dan komentar dari ahli materi. Pada validasi kedua diperoleh skor 42 yang termasuk kategori "layak". Tetapi karena masih terdapat beberapa kesalahan, sehingga perlu dilakukan perbaikan. Perbaikan yang dilakukan antara lain perbaikan istilah, perbaikan nama latin dan perbaikan materi. Validasi dilakukan sebanyak tiga kali untuk mendapatkan kualitas produk yang lebih meyakinkan.

Setelah revisi dilakukan, media kembali diserahkan kepada ahli materi untuk validasi tahap ke tiga. Pada hasil validasi tahap ketiga ini menunjukkan peningkatan hasil penilaian validasi materi. Secara keseluruhan, hasil validasi materi dari tahap pertama dan tahap ke dua hingga didapatkan peningkatan skor dari 38 menjadi 42. Pada validasi materi tahap ke tiga diperoleh skor 51 yang termasuk dalam kategori "sangat layak". Media dinyatakan layak ujicoba setelah revisi sesuai saran ahli. Secara keseluruhan 
persentase hasil validasi oleh ahli materi disajikan pada gambar 2 .

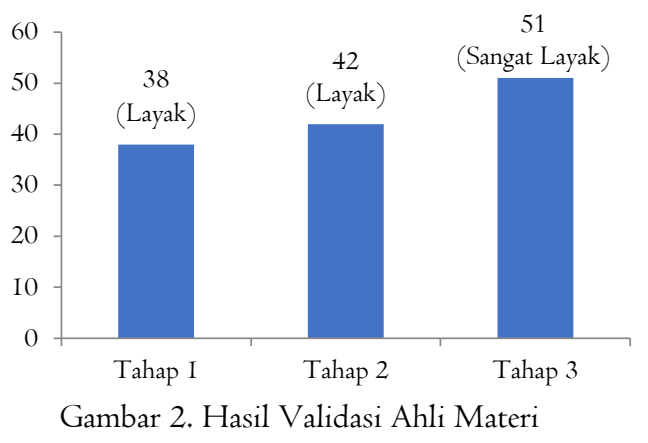

Pada validasi ahli materi, terdapat 5 aspek yang dibagi menjadi 15 kriteria penilaian terhadap media video mengenai mangrove yang dihasilkan. Pada aspek relevansi tujuan pembelajaran terbagi menjadi tiga kriteria yakni kesesuaian materi dengan tujuan, kesesuaian materi dengan kebutuhan dan kesesuaian materi dengan potensi lokal. Pada validasi pertama, aspek ini mendapat skor 2 (tidak layak) sehingga harus diperbaiki terlebih dahulu. Setelah diperbaiki, skor yang diperoleh adalah 3 (layak). Untuk menghasilkan media video pembelajaran mengenai mangrove yang baik maka aspek ini harus dipenuhi agar materi yang disampaikan sesuai dengan tujuan. Hal tersebut juga ditegaskan oleh Asyhar (2012), bahwa kriteria media pembelajaran yang baik diantaranya cocok dengan sasaran, relevan dengan topik, dan sesuai dengan tujuan pembelajaran.

Aspek berikutnya yakni kejelasan isi materi, yang mencakup keakuratan materi, kebenaran materi dan susunan materi. Pada validasi pertama media video mengenai mangrove diperoleh skor 2 (tidak layak), sehingga harus diperbaiki. Validasi berikutnya diperoleh skor 3 (layak), sehingga video pembelajaran mengenai mangrove yang dikembangkan dari segi sajian isi materi layak untuk digunakan. Media yang digunakan adalah media yang mengandung informasi atau pesan materi yang bertujuan instruksional (Arsyad, 2013).

Pada aspek relevansi materi yang terdiri atas kriteria ketepatan penggunaan istilah ilmiah/ bahasa ilmiah dan contoh/skema/gambar/foto yang relevan dengan materi mendapatkan skor 2 (tidak layak), sehingga media harus diperbaiki. Perbaikan juga dilakukan pada beberapa istilah ilmiah yang tidak sesuai. Setelah dilakukan perbaikan, skor penilaian validator meningkat menjadi 3 (layak) pada validasi kedua. Pada validasi ketiga, materi yang digunakan dalam penjelasan sudah sesuai sehingga diperoleh skor 4 (sangat layak).

Pada aspek penyajian terdiri atas beberapa kriteria yakni kejelasan materi, kemampuan untuk membantu memahami, penyajian materi, serta keutuhan konsep. Aspek ini mendapat penilaian yang baik yakni skor 4 (sangat layak).

Aspek penilaian terakhir yakni dari segi manfaat yang terdiri atas berbagai kriteria seperti menarik, meningkatkan pengetahuan dan memotivasi. Aspek ini juga mendapatkan penilaian 4 (sangat layak). Video pembelajaran mengenai mangrove telah dikembangkan secara menarik sehingga dapat meningkatkan motivasi dan pengetahuan penggunanya. Hal ini juga sejalan dengan Munadi (2012), yang menyatakan bahwa media dapat membangkitkan minat belajar, menarik dan memusatkan perhatian siswa, meningkatkan pengetahuan serta memotivasi siswa.

Hasil validasi oleh ahli media diperoleh beberapa saran perbaikan terhadap produk yang berkenaan dengan desain media. Pada proses validasi tahap pertama diperoleh skor 35 dengan kategori tidak layak. Beberapa saran dan masukan dari ahli media pada validasi pertama antara lain (1) kalimat narasi yang perlu dipersingkat serta penggunaan kata yang lebih operasioanl, (2) Perbaikan beberapa kalimat, termasuk pengucapan nama ilmiah, (3) ukuran huruf yang lebih diperkecil, (4) perbaikan tata letak tulisan, (5) perbaikan gambar background, dan (6) perbaikan warna gambar.

Setelah dilakukan perbaikan sesuai saran dan komentar ahli media, kemudian dilanjutkan pada proses validasi tahap kedua. Hasil validasi tahap kedua diperoleh skor 48 dengan kategori layak. Pada validasi kedua ini, produk tidak lagi mendapat revisi dan sudah dinyatakan layak ujicoba tanpa revisi. Dari validasi pertama ke validasi kedua diperoleh peningkatan skor dari 35 (kategori "tidak layak") menjadi skor 48 (kategori "layak"). Persentase hasil validasi oleh ahli media disajikan pada gambar 3 .

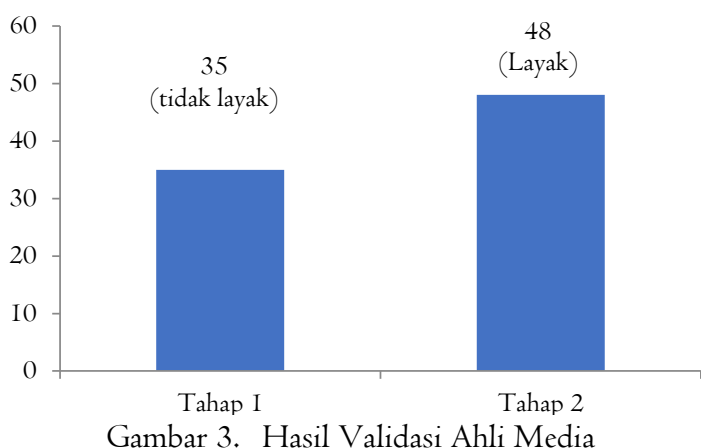

Terdapat 6 aspek yang dibagi menjadi 15 kriteria penilaian dalam validasi media. Aspek pertama yakni penggunaan bahasa yang terbagi menjadi beberapa kriteria penilaian seperti bahasa yang komunikatif, penggunaan kalimat yang lugas dan tidak terlalu padat, serta kalimat narasi yang jelas. Beberapa kriteria masih mendapatkan saran dari ahli 
media sehingga perlu dilakukan perbaikan. Perbaikan yang dilakukan antara lain kalimat yang lebih dipersingkat dan lebih operasional. Media video sebaiknya menggunakan bahasa yang sederhana, mudah dimengerti dan menggunakan bahasa yang umum (Riyana, 2007). Selanjutnya pada aspek manfaat, video mengenai mangrove dapat digunakan sebagai media pembelajaran serta memberikan informasi ilmiah. Media pembelajaran dapat memperluas cakrawala materi pembelajaran serta dapat memberikan informasi-informasi materi yang terbaru dan terakurat (Asyhar, 2012).

Aspek berikutnya yakni tampilan yang memiliki beberapa kriteria penilaian seperti tata letak tulisan yang sesuai sehingga dapat dibaca dengan mudah. Menurut validator media, video masih perlu diperbaiki, yakni letak tulisan yang lebih proporsional, warna dan ukuran huruf yang lebih sesuai sehingga tidak membingungkan. Kriteria ini mendapatkan skor 2 (tidak layak), sehingga harus diperbaiki. Adapun perbaikan yang dilakukan antara lain huruf diperkecil sehingga background video lebih terlihat.

Kriteria yang juga mendapat skor 2 (tidak layak) adalah penampilan/efek transisi video sesuai untuk pembelajaran. Perbaikan yang dilakukan antara lain warna yang lebih dikuatkan/kontras. Pada validasi kedua, media pembelajaran berupa video mengenai mangrove telah dinyatakan layak dan mendapatkan skor 3 (layak). Mengikuti pendapat Riyana (2007) materi sebaiknya dikemas dalam bentuk video yang di dalamnya terdapat teks, animasi, suara, gambar dan cuplikan video.

Aspek lainnya yang juga mendapatkan skor 2 (tidak layak) adalah unsur visual yakni penggunaan ilustrasi seperti gambar, serta grafik atau skema yang memudahkan pemahaman. Adapun saran dari validator media yakni pemberian judul pada gambar zonasi mangrove. Pada unsur audio yakni kesesuaian kombinasi antara suara narrator dan musik latar juga mendapat skor 2 (tidak layak). Perbaikan dilakukan dengan memperjelas suara. Setelah dilakukan perbaikan, media pun dinyatakan layak digunakan dengan skor 3 (layak). Seperti halnya penelitian yang dilakukan oleh Suryansah \& Suwarjo (2016), video ini memiliki suara berupa alunan musik, ilustrasi penjelas, serta suara yang diambil dari kondisi nyata. Kelebihan ini dapat mendasari video mengenai mangrove sebagai media yang efektif dalam pembelajaran.

Aspek berikutnya yang juga mendapatkan skor 2 (tidak layak) adalah kriteria media, durasi waktu sesuai dengan kebutuhan pembelajaran. Hal ini karena video dianggap terlalu lama. Menurut Daryanto (2010) ukuran tampilan video bisa sangat fleksibel dan dapat diatur sesuai kebutuhan. Untuk itu video pembelajaran mengenai mangrove dibagi menjadi tiga bagian. Bagian pertama yakni pendahuluan, bagian kedua konsep mangrove secara teoritik, dan bagian ketiga mengenai hubungan antara mangrove dan masyarakat.

Aspek Penyajian, menurut ahli media aspek resolusi video/gambar/foto dari media yang dihasilkan sudah baik (jelas). Namun masih ada beberapa perbaikan yang dilakukan yakni penggantian gambar akasia, serta perbaikan pada gambar yang kabur (dipotong). Kriteria terakhir yakni kesinambungan antar adegan satu dengan adegan yang lain. Menurut Arsyad (2007), video pembelajaran yang baik harus memiliki teknik khusus, untuk pengaturan urutan baik dalam hal penyajian maupun penyimpanan. Dalam hal ini perbaikan dilakukan dengan lebih memperhalus lagi pergantian antar topik adegan dengan topik adegan lainnya.

Tahap ujicoba pertama dilakukan pada 12 orang siswa kelas XI IPA SMAN 6 Tanjung Jabung Timur yang terdiri atas siswa dengan kemampuan rendah, sedang dan tinggi dengan jumlah masing-masing sebanyak 4 orang siswa. Ujicoba dilakukan pada kelas XI karena siswa telah mempelajari mengenai ekosistem pada kelas sebelumnya (kelas X). Indikator penilaian media pembelajaran terdiri atas lima indikator. Secara keseluruhan diperoleh skor 410 atau $85,4 \%$ termasuk dalam kategori "sangat baik". Dengan demikian dapat disimpulkan bahwa produk video mengenai mangrove yang telah dikembangkan telah layak digunakan dalam proses pembelajaran, baik di kelas maupun sebagai media pembelajaran mandiri. Hal ini didukung oleh Ljubojevic, Vaskovic, Stankovic, \& Vaskovic (2014), yang menyatakan bahwa penggunaan video sebagai bahan pelengkap dapat meningkatkan efisiensi proses pembelajaran. Hal senada juga diungkapkan Donkor (2011), yang menunjukkan bahwa siswa lebih menanggapi positif dan menerima dengan baik materi pembelajaran yang berbasis video.

Pada ujicoba tersebut juga diperoleh saran-saran antara lain: 1) gambar video yang perlu lebih diperbanyak, sehingga dapat memperluas pengetahuan tentang mangrove; 2) masih ada beberapa bagian dari video yang belum dipahami. Saran dan masukan yang bersifat kesan pribadi dari subjek ujicoba tidak diterapkan dalam perbaikan produk karena bukan termasuk dalam kategori data penting. Hasil ujiicoba produk pada siswa secara keseluruhan terlihat pada gambar 4.

Pada aspek fungsi media, penilaian terdiri atas beberapa kriteria yakni meningkatkan pengetahuan, memotivasi dan menumbuhkan rasa ingin tahu. Aspek ini mendapatkan penilaian 87,5 (sangat baik) dari siswa. Hal ini mengindikasikan bahwa media telah 
berhasil memenuhi fungsinya sebagai media pembelajaran yang baik. Sebagaimana yang dikemukakan oleh Munadi (2012), bahwa media pembelajaran memiliki fungsi psikologis yakni membangkitkan minat belajar, menarik dan memusatkan perhatian siswa, meningkatkan pengetahuan serta memotivasi belajar siswa.

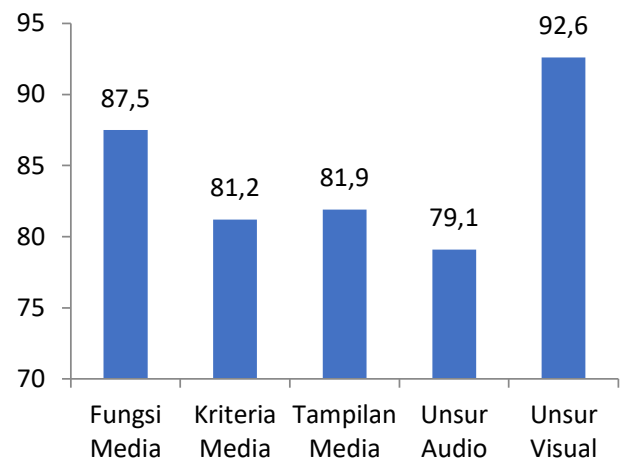

Gambar 4. Hasil ujicoba produk video kepada siswa

Aspek kriteria video sebagai media pembelajaran yang dapat dipelajari secara mandiri. Pada aspek ini media mendapatkan penilaian 81,25 (sangat baik), video dapat dijalankan dengan mudah dan mendukung pembelajaran mandiri. Menurut Arsyad (2013) video sebaiknya dapat disimpan dan dapat dioperasikan dengan mudah.

Aspek tampilan yakni tampilan tulisan, penggunaan ilustrasi dan penggunaan bahasa mendapatkan skor 81,9 (sangat baik). Menurut Asyhar (2012), kriteria media pembelajaran yang berkualitas dapat dilihat dari segi tampilan maupun bahan, serta sesuai dengan lingkungan belajarnya. Media video pembelajaran mengenai mangrove yang dikembangkan sudah memiliki tampilan yang menarik.

Video sebagai media audiovisual akan menampilkan unsur gambar (visual) dan suara (audio) secara bersamaan pada saat mengkomunikasikan pesan atau informasi. Untuk aspek unsur audio dan unsur visual, masing-masing mendapatkan penilaian sangat baik yakni 79,1 dan 92,6. Video mengenai mangrove telah melewati tahap pengembangan dengan serangkaian komponennya seperti musik latar dan suara penjelasan narrator, penyajian gambar/video serta melibatkan potensi lokal daerah (Asyhar, 2012).

Ujicoba kedua dilakukan pada 9 kelompok masyarakat yang dipilih berdasarkan tiga kriteria tingkat pendidikan yaitu (1) tingkat pendidikan diwakili oleh lulusan Strata 1, (2) lulusan SMP/SMA, dan (3) lulusan SD. Kategori jenis pekerjaan diwakili oleh jenis pekerjaan PNS, petani, nelayan, dan ibu rumah tangga. Untuk kategori keikutsertaan pada komunitas, diwakili oleh Kelompok Nelayan "Ratu" dan Kelompok Tani
"Sumber Rezeki". Pemilihan kelompok ini didasarkan pada kelompok yang paling dominan di masyarakat.

Hasil penilaian dari indikator 1 sampai indikator 5 mendapatkan hasil "sangat baik", dengan skor 1.222 atau $84,8 \%$. Masyarakat memberikan respon positif terhadap video pembelajaran mengenai mangrove. Penggunaan video dapat menambah wawasan mereka mengenai lingkungan di sekitarnya, khususnya mengenai hutan mangrove. Sejalan dengan penelitian Makarem (2015), penggunaan video juga merupakan cara yang efektif untuk melakukan pembelajaran yang bebas di luar kelas.

Ujicoba pada kelompok masyarakat juga mendapatkan beberapa saran dan masukan, antar lain: 1) video masih terlalu cepat, sebaiknya bisa sedikit diperlambat; 2) sebaiknya ditambahkan peraturan yang berlaku, sehingga lebih mengikat masyarakat. Dari saran dan masukan yang didapat, tidak ada yang diterapkan dalam merevisi produk yang dikembangkan karena berbagai pertimbangan. Adapun secara keseluruhan hasil ujicoba masyarakat dapat dilihat pada gambar 5 .

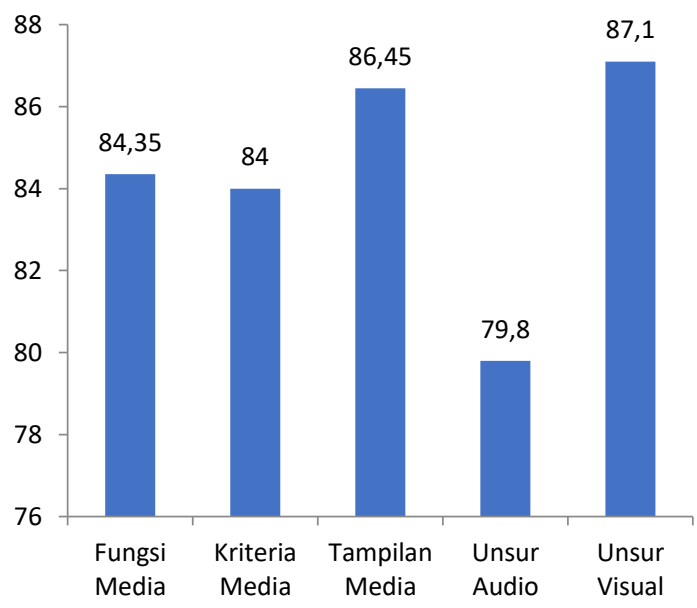

Gambar 5. Hasil Ujicoba produk video kepada Masyarakat

Dari segi fungsi, video yang dikembangkan dapat memperjelas informasi, meningkatkan pengetahuan pada masyarakat, melibatkan potensi lokal daerah dan sebagai media informasi. Masyarakat Desa Sungai Itik memberikan penilaian 84,5 yakni sangat baik, sehingga media pembelajaran berupa video mengenai mangrove telah memenuhi fungsinya sebagai media pembelajaran yang baik. Penyajian materi yang terstruktur dalam video pembelajaran juga memudahkan masyarakat dalam memahaminya (Sudiarta \& Sadra, 2016).

Kriteria media menggunakan bahasa yang sederhana, hasil ujicoba mendapatkan penilaian 84 (sangat baik) dari masyarakat. Hal ini mengindikasikan bahwa video pembelajaran mengenai mangrove telah menggunakan bahasa yang sederhana, 
sehingga mudah untuk dipahami oleh masyarakat. Riyana (2007) menekankan bahwa media video perlu menggunakan bahasa yang sederhana, mudah dimengerti, serta menggunakan bahasa yang umum.

Aspek tampilan tulisan, kualitas, suara narator, ilustrasi gambar dan tampilan desain mendapatkan penilaian berturut-turut 86,45 ; 79,8; dan 87,1 yang termasuk dalam kategori sangat baik. Menurut Riyana (2007) materi dalam video sebaiknya dikemas dengan baik, serta dikombinasikan dengan teks, animasi, suara. Video juga perlu menggunakan kualitas resolusi yang tinggi, serta dapat digunakan pada berbagai jenis komputer (Riyana, 2007).

Media yang dikembangkan telah melewati serangkaian tahapan penilaian dan perbaikan hingga dianggap layak oleh ahli materi dan ahli media, dan telah dilakukan ujicoba. Secara keseluruhan terdapat perbedaan dari produk awal hingga menjadi produk akhir yang layak untuk ujicoba. Perbedaan tersebut terutama berasal dari revisi yang dilakukan berdasarkan saran dan masukan dari tim validator dan hasil ujicoba. Perbedaannya meliputi aspek materi dan aspek media.

Aspek materi, perubahan terdapat pada perbaikan pengertian mangrove serta pengertian mengenai bakau untuk memberikan pemahaman bahwa mangrove dan bakau berbeda, penambahan contoh mangrove asosiasi (transisi antara daratan dan perairan), konsistensi penggunaan nama latin, perbaikan beberapa kata-kata yang kurang sesuai, penambahan beberapa materi yang mendukung, serta mengganti gambar zonasi mangrove yang lebih sesuai. Pada aspek media, perubahannya meliputi perbaikan ukuran huruf yang lebih diperkecil, perbaikan tata letak tulisan, penambahan judul pada gambar zonasi mangrove, penggantian dan pemotongan gambar yang tidak sesuai dan kabur, kalimat yang lebih dipersingkat dan perbaikan kesalahan tulis.

Perbaikan dilakukan berdasarkan saran dan masukan dari ahli media dan ahli materi. Akhirnya dihasilkan tiga bagian video yaitu bagian pertama berupa opening yang berisi pendahuluan (tujuan, indikator dan pengenalan video) tersedia pada gambar 6. Video bagian pertama ini memiliki durasi 3 menit 45 detik.
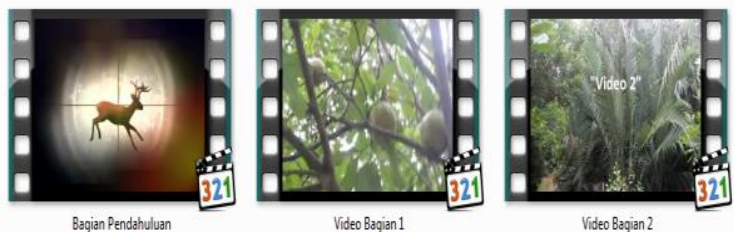

Gambar 6. Bagian-Bagian Utama Video

Video bagian kedua membahas mengenai mangrove secara teoritik, yaitu menjelaskan mengenai hubungan antara manusia dengan ekosistem mangrove (gambar 7 dan gambar 8). Pokok bahasan video bagian kedua meliputi pengertian mengenai mangrove, luas dan penyebaran mangrove, jenis-jenis mangrove, ciri-ciri, pola zonasi dan bentuk adaptasi mangrove, serta fungsi dan manfaat mangrove baik dari aspek ekologi, ekonomi maupun sosial budaya. Durasi video bagian ke dua ini sebanyak 19 menit 36 detik. Berikut beberapa gambar yang mewakili video bagian kedua.

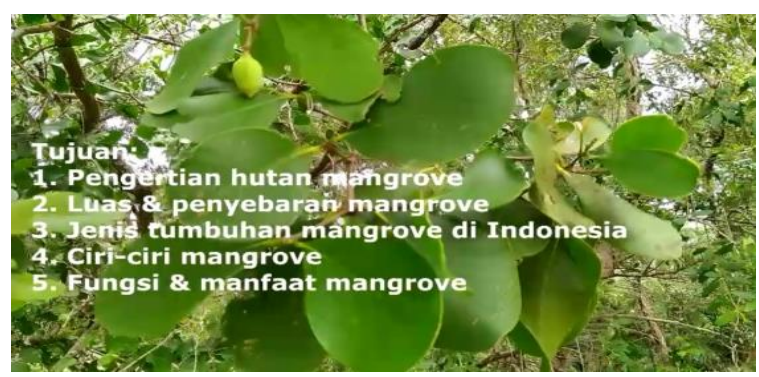

Gambar 7. Video Bagian 1: Tujuan Pembelajaran

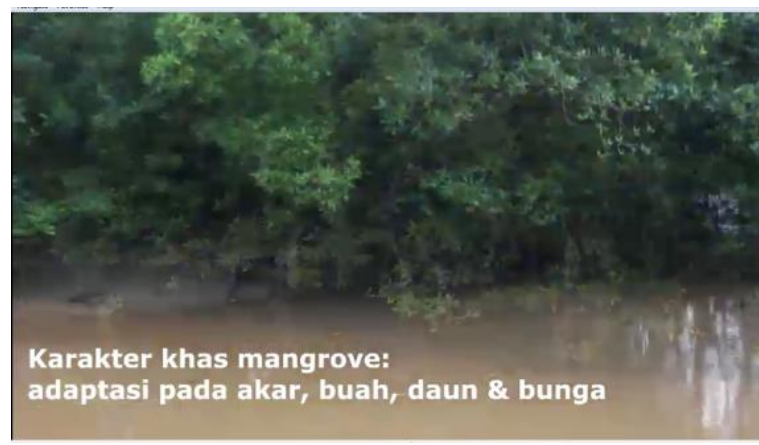

Gambar 8. Karakter khas pada mangrove

Video bagian ke tiga menjelaskan mengenai hubungan antara manusia dengan mangrove tersaji pada gambar 9. Durasinya selama 17 menit dan 13 detik. Adapun tujuan dari video bagian ke tiga yaitu mengenal dan mengetahui berbagai aktivitas masyarakat di daerah pesisir, terutama masyarakat yang tinggal di pesisir Jambi, mengetahui ancaman kerusakan dan dampak yang ditimbulkan, serta mengetahui usaha apa saja yang dapat dilakukan untuk pelestarian mangrove.

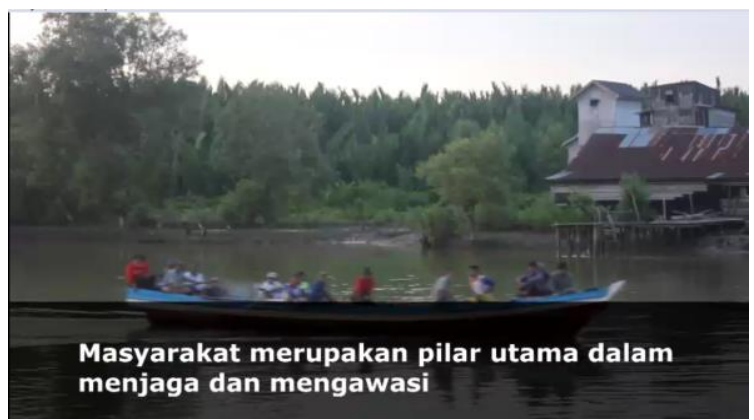

Gambar 9. Video Bagian 2: Masyarakat Pesisir Jambi di sekitar Hutan mangrove 
Media pembelajaran berupa video mengenai mangrove telah berhasil dikembangkan dan mendapatkan penilaian yang baik, serta memiliki beberapa kelebihan. Adapun kelebihan dari produk video media pembelajaran yang dikembangkan yaitu: (1) Materi disajikan secara sederhana sehingga dapat menunjang dan membantu siswa dan masyarakat untuk lebih mudah mengenal mangrove; (2) Video ini dikembangkan berdasarkan potensi mangrove yang terdapat di Tanjung Jabung Barat dan Tanjung Jabung Timur, Propinsi Jambi. Dengan demikian diharapkan dapat memotivasi siswa dan masyarakat dalam mempelajari potensi alam di sekitarnya serta potensi daerah lainnya. Hal ini juga sejalan dengan penelitian Utami, Wibowo, \& Rahayu (2017), bahwa materi yang disajikan melalui media video lebih mudah dipahami dan lebih sesuai dengan kejadian dalam kehidupan sehari-hari; (3) Produk video menarik dan tidak hanya berupa kata-kata tetapi juga memuat cuplikan klip, gambar, foto, teks, serta audio yakni suara latar dan penjelasan materi. Video sebagai media memiliki tampilan menarik dengan gambar riil yang bergerak, yang disampaikan dalam audiovisual serta memotivasi siswa untuk mempelajari materi lebih banyak (Andarini, Masykuri, \& Sudarisman, 2012); (4) Video yang dihasilkan memiliki sifat yang praktis, mudah dioperasikan, dan dapat digunakan baik secara formal maupun nonformal, baik secara individu maupun klasikal; (5) Video dapat dioperasikan menggunakan semua jenis komputer (PC), laptop dan notebook; (6) Video dapat dipindahkan/dicopykan ke dalam Flasdisk (FD) atau pun Compactdisk (CD); (7) Video dapat digunakan oleh seluruh lapisan masyarakat, baik pelajar, penggiat pendidikan maupun masyarakat biasa; dan (8) Video terdiri atas 2 bagian yakni video bagian 1 membahas mengenai mangrove secara teoritik, sedangkan video bagian 2 membahas hubungan antara manusia dan mangrove. Dengan adanya pemisahan tersebut, video dapat ditonton secara terpisah untuk masing-masing bagian.

Produk video media pembelajaran mengenai mangrove ini juga memiliki beberapa kekurangan antara lain: (1) video masih menyajikan materi secara umum, sehingga masih memerlukan bimbingan untuk penguasaan materi; (2) Pemutaran video memerlukan alat bantu berupa proyektor untuk penayangan video yang lebih jelas; (3) Desain video masih banyak kekurangan pada beberapa aspek, seperti proses rekaman dan dokumentasi yang masih konvensional, kamera yang digunakan juga masih sederhana, serta tenaga pelaksana yang belum ahli sehingga diperlukan adanya pengembangan lebih lanjut dengan desain yang lebih bervariasi menggunakan perlengkapan rekaman sesuai standar dengan tenaga ahli yang profesional.

\section{Simpulan}

Penelitian pengembangan ini telah menghasilkan media video mengenai mangrove yang dapat digunakan untuk pembelajaran. Video yang dihasilkan dinyatakan layak, baik dari aspek materi maupun media. Ujicoba video pada siswa dan masyarakat, juga mendapatkan tanggapan yang positif (kategori "sangat baik"). Penelitian ini perlu ditindaklanjuti dengan penelitian selanjutnya, terutama untuk menguji sejauh mana efektivitas penggunaan video yang dihasilkan untuk mendukung pembelajaran mengenai mangrove.

\section{Ucapan terima kasih}

Penulis menyampaikan terima kasih dan penghargaan yang tinggi kepada berbagai pihak yang telah membantu pelaksanaan penelitian di lapangan Bapak Zainar , S.H (Kepala Desa Sungai Itik), Bapak Ahmadi (Kepala Desa Pangkal Babu), Ibu Asiah S.Pd.I. (Kepala SMAN 6 Tanjung Jabung Timur), keluarga besar Ibu Dewi, Pak Sutar, Kak Rida, Kak Fila, Pak Usman, masyarakat Desa Sungai Itik, masyarakat Desa Pangkal Babu, serta mahasiswa Tim Penelitian Tanjung Jabung Timur (Sadu). Selanjutnya penulis juga menyampaikan penghargaan dan terima kasih kepada Sivitas akademika Prodi Pendidikan Biologi Universitas Jambi yang telah memberikan saran dan masukan untuk perbaikan hasil penelitian ini, khususnya kepada Bapak Drs. Gardjito, M.Pd. (alm), Ibu Winda Dwi Kartika, S.Si., M.Si., serta Ibu Retni S. Budiarti, S.Pd., M.Si.

\section{Referensi}

Ali, M., \& Ansori, M. (2014). Metodologi \& aplikasi riset pendidikan. Jakarta: Bumi Aksara.

Andarini, T., Masykuri, M., \& Sudarisman, S. (2012). Pembelajaran biologi menggunakan pendekatan CTL (Contextual Teaching and Learning) melalui media flipchart dan video ditinjau dari kemampuan verbal dan gaya belajar. JURNAL INKUIRI, 1(2), 93-104. Diambil dari http://jurnal.pasca.uns.ac.id

Arsyad, A. (2007). Media pembelajaran. Jakarta: Raja Grafindo Persada.

Arsyad, A. (2013). Media pembelajaran. Jakarta: Rajawali Press.

Asyhar, R. (2012). Kreatif mengembangkan media pembelajaran. Jakarta: Gaung Persada Press.

Choi, H. J., \& Johnson, S. D. (2005). The effect of contextbased video instruction on learning and motivation in online courses. American Joumal of Distance Education, 194), 215-227. https://doi.org/10.1207/s15389286ajde1904_3 
Daryanto. (2010). Media pembelajaran. Yogyakarta: Gava Media.

Donkor, F. (2011). Assessment of learner acceptance and satisfaction with video-based instructional materials for teaching practical skills at a distance. The International Review of Research in Open and Distributed Learning, 12(5), 74-92. https://doi.org/10.19173/irrodl.v12i5.953

Hadi, S. (2017). Efektivitas penggunaan video sebagai media pembelajaran untuk siswa sekolah dasar. In Seminar Nasional Teknologi Pembelajaran dan Pendidikan Dasar 2017 (hal. 96-102). Malang: Universitas Negeri Malang. Diambil dari http://pasca.um.ac.id/conferences/index.php/s ntepnpdas/article/view/849/521

Hakim, L. (2017). Pengembangan media video pembelajaran untuk mengembangkan karakter disiplin siswa di SDN Adisucipto 02. E-Jumal Skripsi Mahasiswa TP, 6(8), 777-787. Diambil dari http://journal.student.uny.ac.id/ojs/index.php/fiptp/ article/download/8423/8024

Handziko, R. C., \& Suyanto, S. (2015). Pengembangan video pembelajaran suksesi ekosistem untuk meningkatkan motivasi belajar dan penguasaan kosep mahasiswa biologi. Jurnal Inovasi Pendidikan IPA, 1(2), 212-224. https://doi.org/10.21831/jipi.v1i2.7508

Hsin, W.-J., \& Cigas, J. (2013). Short videos improve student learning in online education. J. Comput. Sci. Coll., 28(5), 253-259. Diambil dari http://dl.acm.org/ citation.cfm?id=2458569.2 458622

Isiaka, B. (2007). Effectiveness of video as an instructional medium in teaching rural children agricultural and environmental sciences. International Journal of Education and Development using ICT, 3(3), 105-114. Diambil dari https://www.learntechlib.org/p/42274/

Kurniawan, R. M., \& Soeprajitno, S. (2017). Pengembangan media video pembelajaran materi pokok invertebrata mata pelajaran biologi untuk meningkatkan hasil belajar siswa kelas X IPA di SMA Persatuan Tulangan Sidoarjo. Jumal Mahasiswa Teknologi Pendidikan, 82), 1-6. Diambil dari http://jumalmahasiswa.unesaacid/index.php/jmtp/artid e/view/20947/19213

Lee, W. W., \& Owens, D. L. (2004). Multimedia-based instructional design: computer-based training, web-based training, distance broadcast training, performance-based solutions. New Jersey: John Wiley \& Sons.

Ljubojevic, M., Vaskovic, V., Stankovic, S., \& Vaskovic, J. (2014). Using supplementary video in multimedia instruction as a teaching tool to increase efficiency of learning and quality of experience. The Intemational Review of Research in Open and Distributed Leaming, 15(3), 275291. https://doi.org/10.19173/irrodl.v15i3.1825
Makarem, S. C. (2015). Using online video lectures to enrich traditional face-to-face courses. Intemational Joumal of Instruction, 82), 155-164. Diambil dari https://files.ericed.gov/fulltext/EJ1085302.pdf

Mayer, R. E. (2003). The promise of multimedia learning: using the same instructional design methods across different media. Learning and Instruction, 13(2), 125-139. https://doi.org/10.1016/S09594752(02)00016-6

Munadi, Y. (2012). Media pembelajaran. Jakarta: Gaung Persada Press.

Pontoh, O. (2011). Peranan nelayan terhadap rehabilitasi ekosistem hutan bakau (mangrove). Jumal Perikanan dan Kelautan Tropis, 72), 73-79. Diambil dari https://ejoumal.unsratac.id/index.php/JPKT/article/vie $\mathrm{w} / 181 / 144$

Restu, R., Berutu, N., Ridha Syafii Damanik, M., \& Suriani Harefa, M. (2017). Model of mangrove ecosystem utilization as media and learning resources of environmental education at senior high school. In Proceedings of the lst International Cohference on Geography and Education (ICGE 2016). Paris, France: Atlantis Press. https://doi.org/10.2991/icge-16.2017.64

Riduwan. (2010). Dasar-dasar statistika. Bandung: Alfabeta.

Riyana, C. (2007). Pedoman pengembangan media video. Jakarta: P3AI UPI.

Salina, L., Ruffinengo, C., Garrino, L., Massariello, P., Charrier, L., Martin, B., ... Dimonte, V. (2012). Effectiveness of an educational video as an instrument to refresh and reinforce the learning of a nursing technique: a randomized controlled trial. Perspectives on Medical Education, 1(2), 67-75. https://doi.org/10.1007/s40037-0120013-4

Saparinto, C. (2007). Pendayagunaan ekosistem mangrove. Semarang: Dahara Prize.

Setyosari, P. (2012). Metode penelitian pendidikan dan pengembangan. Jakarta: Kencana.

Sudiarta, I. G. P., \& Sadra, I. W. (2016). Pengaruh model blended learning berbantuan video animasi terhadap kemampuan pemecahan masalah dan pemahaman konsep siswa. Jumal Pendidikan dan Pengajaran, 492), 48-58. https://doi.org/10.23887/jppundikshav49i2.9009

Sugiyono. (2014). Metode penelitian pendidikan pendekatan kuantitatif, kualitatif dan R\&D. Bandung: Alfabeta.

Suryansah, T., \& Suwarjo, S. (2016). Pengembangan video pembelajaran untuk meningkatkan motivasi dan hasil belajar kognitif siswa kelas IV SD. Jurnal Prima Edukasia, 4(2), 209-221. https://doi.org/10.21831/jpe.v4i2.8393

Utami, D. L., Wibowo, Y., \& Rahayu, T. (2017). Penyusunan media pembelajaran video animasi sistem saraf untuk meningkatkan motivasi belajar siswa kelas XI SMA Negeri 1 Kasihan Bantul. 
Jumal Prodi Pendidikan Biologi, (2), 39-46. Diambil dari http://joumalstudent.uny.ac.id/ojs/ojs/index.php/pbio/ article/view/6176/5885

Yusriya, A., Santosa, K., \& Priyono, B. (2014). Pengembangan video pembelajaran materi klasifikasi hewan sebagai suplemen bahan ajar biologi SMP. Unnes Journal of Biology Education, 3(1), 26-34. Diambil dari https://journal.unnes.ac.id/sju/index.php/ujbe /article/view/4152/3789

Zhang, D., Zhou, L., Briggs, R. O., \& Nunamaker, J. F. (2006). Instructional video in e-learning: Assessing the impact of interactive video on learning effectiveness. Information \& Management, 43(1), 15-27. https://doi.org/10.1016/j.im.2005.01.004 